\title{
SEWAGE SLUDGE BIOCHAR EFFECTS ON PHOSPHORUS MOBILITY IN SOIL AND ACCUMULATION IN PLANT
}

\author{
WPEYW BIOWEGLA Z OSADÓW ŚCIEKOWYCH NA MOBILNOŚĆ FOSFORU \\ W GLEBIE I AKUMULACJE W ROŚLINIE
}

\begin{abstract}
In the course of analysing sewage sludge biochar (BC) as a material containing phosphorus loads, we determined the following: effect of thermal conversion of three different sewage sludge biochars on the content and availability of $\mathrm{P}$ in biochars (BC-1, BC-2 BC-3), effect of their application on selected forms of $\mathrm{P}$ in soil and on the accumulation of this component in Poa pratensis L. biomass. Regardless of the type of BC, the contents of $\mathrm{P}-\mathrm{H}_{2} \mathrm{O}$ and $\mathrm{P}-\mathrm{CaCl}_{2}$ were lower than the contents determined in unconverted sewage sludge. A significant increase in the content of $\mathrm{P}_{-} \mathrm{CaCl}_{2}$ compared to the control was noted in the soil of treatments where 1 and $2 \%$ additions of BC-2 and BC-3 were applied. Soil pH $(r=0.826 ; p \leq 0.05)$ and the content of Ca-exchangeable $(r=0.712$; $p \leq 0.05)$ had the strongest effect on the content of $\mathrm{P}-\mathrm{CaCl}_{2}$ in soil; however, no significant relationship was found between the amount of P-introduced with $\mathrm{BC}$, the contents of $\mathrm{Al}$-ox., $\mathrm{Fe}$-ox. and the content of $\mathrm{P}-\mathrm{CaCl}_{2}$. Significant $(p \leq 0.05)$ increase in the phosphorus content in plant biomass was noted in all treatments compared to the control. Regardless of the type of biochar applied, the highest amount of P-uptake was determined in treatments where the greatest addition of $\mathrm{BC}(2 \%)$ was introduced into the soil. A significant relationship between P-uptake and the amount of P-introduced with BC into the soil $(r=0.726 ; p \leq 0.05)$ was demonstrated.
\end{abstract}

Keywords: plant, soil, phosphorus, sewage sludge biochar

\section{Introduction}

The need to improve methods of managing waste such as sewage sludge is dictated by the systematic increase in their quantity and the growing threat to the environment. The amount of sewage sludge produced in European Union is over $10 \mathrm{Tg}$, and it is estimated that by 2020 it will increase to $13 \mathrm{Tg}$ [1]. Directions of sewage sludge

\footnotetext{
${ }^{1}$ Department of Agricultural and Environmental Chemistry, University of Agriculture in Krakow, al. A. Mickiewicza 21, 31-120 Kraków, Poland, phone +48 1266243 46, fax +48 126624341 , email: krzysztof.gondek@urk.edu.pl,rrgondek@cyf-kr.edu.pl

${ }^{2}$ Institute of Agricultural Engineering and Informatics, University of Agriculture in Krakow, ul. Balicka 116B, 30-149 Kraków, Poland, email: Jakub.Sikora@ur.krakow.pl

${ }^{3}$ Department of Environmentalistics and Natural Resources, Mendel University in Brno, Zemědělská 1/1665, 61300 Brno, Czech Republic, email: tomas.losak@mendelu.cz

${ }^{4}$ Faculty of Chemical and Process Engineering, Warsaw University of Technology, ul. L. Waryńskiego 1, 00-645 Warszawa, Poland, email: p.grzybowski@ichip.pw.edu.pl

*Corresponding author: krzysztof.gondek@urk.edu.pl, rrgondek@cyf-kr.edu.pl
} 
management in European countries usually depend on the country's economic growth indicator. Until now, sewage sludge in Poland has been used mainly in agriculture and land recultivation or has been disposed of in landfills. Due to legislative changes since 2013, there are significant restrictions on the sewage sludge storage. This is mainly related to the carbon content ( $\mathrm{C}$ content cannot exceed $5 \%$ of dry matter) and the heat of combustion (maximum $6 \mathrm{MJ} / \mathrm{kg}$ of dry matter) [2].

Considering substantial technological progress in the field of waste substance treatment, thermal methods of municipal sewage sludge conversion are at the forefront. Such a form of municipal sewage sludge conversion may give a product that can be re-used in nature.

Studies carried out by Qian and Jiang [3] proved that the application of phosphorus accumulated in thermally converted sewage sludge is an important element of the global $\mathrm{P}$ flows, which is of great importance in the aspect of raw materials critical for the UE [4]. The low availability of $\mathrm{P}$ for plants is a global problem, limiting plant production especially in arid and semi-arid regions of the world. Due to the care for the natural environment, more and more emphasis is placed on sustainable fertilisation aimed at improving the retention of key nutrients for plants, such as $\mathrm{P}$. The management of $\mathrm{P}$ reserves in soil is difficult, because its uptake by plants is closely related to, inter alia, soil $\mathrm{pH}$. Insoluble and inaccessible to plants phosphorus compounds can be formed in a very acidic environment, when the activity of $\mathrm{Fe}, \mathrm{Al}$, or $\mathrm{Mn}$ ions is increased, as well as in alkaline environment, when there is a risk of binding with $\mathrm{Ca}$ and $\mathrm{Mg}$ ions. The global demand for food is constantly growing which, at the same time, increases the demand for fertilisers containing P. Therefore, attention should be paid to the depletion of phosphate rock resources and the problem of decreasing amount of raw materials for the production of fertilisers containing phosphorus [4-6].

There are many studies devoted to the subject of increasing the effectiveness of fertilising with fertilisers containing P. However, only a few studies are focused on the use of sewage sludge biochar to increase its amount in soil. This is somewhat surprising, because for many years biochar has been known as an organic P fertiliser [7]. Recently, also Arif et al. [8] have noticed that, despite the availability of data on the mechanisms for the uptake and use of $\mathrm{P}$ by plants from soils fertilised with conventional fertilisers, information on the effectiveness of phosphorus use by various plants from soils fertilised with biochar is very limited.

It should be noted that in the process of thermal conversion organic compounds containing $\mathrm{P}$ (phytates, lipids) are transformed into mineral forms (e.g. $\mathrm{FePO}_{4}, \mathrm{AlPO}_{4}$ and $\mathrm{CaPO}_{4}$ ). Unlike organic compounds, mineral forms of $\mathrm{P}$ do not require enzymatic hydrolysis with phytase and alkaline phosphatases [6]. The total $\mathrm{P}$ content in solid products of thermal conversion depends on the conditions of the pyrolysis process and is generally higher that the content in the feedstock used. As stated by Novak et al. [9], the application of biochar to soil increases the retention of P. Sandeep et al. [10] discovered that the application of biochar to soil influences the availability of phosphorus but is determined by the soil type. In addition, Prendergast-Miller et al. [11] reported that the addition of biochar can inhibit the development of root hairs which are most responsible for the uptake of water and minerals from the soil. According to Prendergast-Miller et al. [11], this phenomenon is due to the greater availability of $\mathrm{P}$ in the soil enriched with biochar.

Considering the lack of unambiguous opinion about and understanding of the potential of biochar in increasing the phosphorus content available for plants, especially in 
low-fertile, light and acidic soils, comprehensive studies were conducted aimed at: (i) determining the total $\mathrm{P}$ content and the $\mathrm{P}$ content available for plants in sewage sludge and sewage sludge biochars, (ii) determining the total and available $\mathrm{P}$ contents in soil after the application of $\mathrm{BC}$, and (iii) assessing the use of $\mathrm{P}$ from the soil fertilised with sewage sludge biochar by determining the amount of P-uptake by Poa pratensis L. biomass.

\section{Materials and methods}

\section{Soil, sewage sludge and biochars}

Studies were carried out with the use of acidic soil (loamy sand) containing $50 \mathrm{~g} / \mathrm{kg}$ of particles with a diameter of $<0.02 \mathrm{~mm}$, collected from $0-20 \mathrm{~cm}$ layer in southern Poland. The soil contained $165 \mathrm{mg} / \mathrm{kg}$ d.m. (dry matter) of total phosphorus and had the natural content of trace elements. The properties of the soil used in the tests are presented in Table 1.

Biochars were produced from stabilised municipal sewage sludge. Sewage sludge came from wastewater treatment plants in which the system of mechanical and biological wastewater treatment is used. Sewage sludge was collected in Wastewater Treatment Plants in Krakow (SS-1), Krzeszowice (SS-2), and Slomniki (SS-3) (Malopolskie Province).

Thermal conversion of air-cured sewage sludge was carried out under laboratory conditions using biomass gasification unit under a limited supply of air (1-2\%) [12]. Samples of $100 \mathrm{~g}$ were placed in the combustion chamber. Temperature in the combustion chamber was $300 \pm 10^{\circ} \mathrm{C}$, and exposure time was 15 minutes.

Selected chemical and physical properties of soil

\begin{tabular}{|c|c|c|}
\hline Determination & Unit & Value \\
\hline $\mathrm{pH}\left(\mathrm{H}_{2} \mathrm{O}\right)$ & {$[-]$} & $5.79 \pm 0.07$ \\
\hline $\mathrm{pH}(\mathrm{KCl})$ & {$[-]$} & $4.60 \pm 0.01$ \\
\hline Hydrolytic acidity, $H h$ & {$[\mathrm{mmol}(+) / \mathrm{kg} \mathrm{d} . \mathrm{m}]$.} & $27 \pm 3$ \\
\hline Electrical conductivity, $E C$ & {$[\mu \mathrm{S} / \mathrm{cm}]$} & $21 \pm 9$ \\
\hline Soil Organic C & [g/kg d.m.] & $4.20 \pm 0.10$ \\
\hline N-total & [g/kg d.m.] & $0.87 \pm 0.04$ \\
\hline P-total & [g/kg d.m.] & $0.17 \pm 0.00$ \\
\hline $\mathrm{P}-\mathrm{CaCl}_{2}$ & [mg/kg d.m.] & $1.54 \pm 0.16$ \\
\hline Ca-exch. & [mg/kg d.m.] & $103 \pm 3$ \\
\hline Mg-exch. & [mg/kg d.m.] & $11 \pm 0$ \\
\hline $\mathrm{Fe}-\mathrm{ox}$ & [mg/kg d.m.] & $746 \pm 43$ \\
\hline Al-ox. & [mg/kg d.m.] & $541 \pm 47$ \\
\hline Sand & [g/kg d.m.] & $870 \pm 56$ \\
\hline Silt & [g/kg d.m.] & $80 \pm 6$ \\
\hline Clay & [g/kg d.m.] & $50 \pm 4$ \\
\hline
\end{tabular}

Each value represents the mean of three replicates $\pm S D$ (standard deviation), d.m. - dry matter

In order to identify the properties of biochars used in the studies (BC-1, BC-2, BC-3), they were ground in a laboratory mill $\left(1 \mathrm{~mm}\right.$ sieve mesh diameter), then dried at $105{ }^{\circ} \mathrm{C}$ for 12 hours [13] and analysed. The $\mathrm{pH}$ of biochars (biochar : water $=1: 5$ ) was determined electrochemically using a $\mathrm{pH}$-meter (pH-meter CP-505). Elemental composition $(\mathrm{C}, \mathrm{H}, \mathrm{N}$, S) was determined using a CHNS Vario EL Cube analyser manufactured by Elementar. 
Content $\mathrm{O}[\% \mathrm{w} / \mathrm{w}]$ was derived by subtraction according to DIN 51733 [7] method as follows (1):

$$
\mathrm{O}=100-(\operatorname{ash}+\mathrm{C}+\mathrm{N}+\mathrm{H}+\mathrm{S})
$$

where: ash - ash content $[\% \mathrm{w} / \mathrm{w}], \mathrm{C}$ - carbon content $[\% \mathrm{w} / \mathrm{w}], \mathrm{N}$ - nitrogen content [\% w/w], H - hydrogen content [\% w/w] and S - sulphur content [\% w/w].

Total contents of ash elements, including P-total, were determined after ashing the sample in chamber furnace at $450{ }^{\circ} \mathrm{C}$ for 12 hours and mineralising its residues in a mixture of concentrated nitric and perchloric acids $(3: 2)(\mathrm{v} / \mathrm{v})$. The content of $\mathrm{P}^{-} \mathrm{H}_{2} \mathrm{O}$ was determined after extraction with redistilled water (material $:$ water $=1: 10$ ), and of $\mathrm{P}-\mathrm{CaCl}_{2}$ after extraction with $0.01 \mathrm{M}$ of $\mathrm{CaCl}_{2}$ (material : solution $=1: 10$ ). The contents of $\mathrm{P}$ and other macroelements in the obtained solutions and extracts were determined by inductively coupled plasma optical emission spectrometry (ICP-OES, Perkin Elmer Optima 7300 DV) [14].

Specific surface area $\left(S_{B E T}\right)$ of organic materials and pore volume $\left(V_{t o t}{ }^{0.99}\right)$ were determined using multifunction accelerated surface area and porosimetry analyser ASAP 2010 manufactured by American company - Micromeritics. $S_{B E T}$ was determined by physical nitrogen adsorption at liquid nitrogen temperature $\left(-196{ }^{\circ} \mathrm{C}\right)$ using Brunauer-Emmett-Teller equation. Before measuring specific surface area, test samples were subjected to desorption at $105{ }^{\circ} \mathrm{C}$ under vacuum conditions, and washed with pure helium. Sample degassing time was 16 hours. The status of surface degassing was controlled in an automatic manner [15].

\section{Growing experiment}

Growing tests were carried out under laboratory conditions in PVC containers containing $500 \mathrm{~g}$ of soil to which $0.5,1$, and $2 \%$ (w/w) of BC-1, BC-2, and BC-3 biochars were added. The control sample (soil) was stored with no biochar added. After introducing biochars into the soil, the material was wetted with distilled water and thoroughly mixed. Then, the soils with and without additions of biochars were placed in PVC containers. After 24 hours, $P$. pratensis seeds of Bariris variety were sown. During plant vegetation, moisture content in the soil sample was maintained at $50 \%$ of soil water capacity. The moisture loss was supplemented with distilled water to the calculated mass of the soil container. The experiment was conducted for 200 days. After that time, the aboveground parts of plants were collected, the roots were separated from the soil and thoroughly washed with distilled water. The collected biomass of aboveground parts and roots was dried to a constant weight at $105^{\circ} \mathrm{C}$ and then, its amount was determined.

\section{Selected chemical properties of soil}

The following parameters were determined in dried and $1 \mathrm{~mm}$ sieved soil samples: $\mathrm{pH}$ - potentiometrically in the suspension of soil and $1 \mathrm{M} \mathrm{KCl}$ (soil : solution = $1: 2.5$ ), electrical conductivity $(E C)$ - conductometrically (soil : solution $=1: 2.5$ ). The carbon content was determined on CNS analyser (Vario MAX Cube, Elementar). Exchangeable calcium (Ca-exch.) and magnesium (Mg-exch.) were extracted with $1 \mathrm{M}$ ammonium acetate $(\mathrm{pH}=7)$ [16]. Poorly crystalline iron (Fe-ox.) and aluminium (Al-ox.) were extracted with $0.2 \mathrm{M}$ ammonium oxalate buffer solution $(\mathrm{pH}=3)$ [17]. Ca-exch., Mg-exch., Fe-ox. and Al-ox. were determined by inductively coupled plasma optical emission spectrometry (ICP-OES, Perkin Elmer Optima 7300 DV) [14]. Total phosphorus content (P-total) was 
determined after ashing the sample in chamber furnace at $550{ }^{\circ} \mathrm{C}$ for 12 hours and mineralising its residues in a mixture of concentrated nitric and perchloric acids $(3: 2)$ (v/v). P-CaCl 2 was extracted from soil with $0.01 \mathrm{M} \mathrm{CaCl}_{2}$ (soil : solution = $1: 10$ ) [18]. The $\mathrm{P}$ content in the obtained solutions and extracts was determined by inductively coupled plasma optical emission spectrometry (ICP-OES, Perkin Elmer Optima 7300 DV) [14].

\section{Analysis of plant material}

Samples of plant materials were mineralised in a chamber furnace at $450{ }^{\circ} \mathrm{C}$. The residue was dissolved in dilute nitric acid $(1: 2)$, and the $\mathrm{P}$ content was determined in the obtained solutions by inductively coupled plasma optical emission spectrometry (ICP-OES, Perkin Elmer Optima 7300 DV) [14]. In the presented studies, the phosphorus content was presented as the weighted arithmetic mean (P-content $[\mathrm{g} / \mathrm{kg} \mathrm{d}$ d.m.]) for aboveground parts and roots of $P$. pratensis (2):

$$
\mathrm{P} \text {-content }=[(\mathrm{Pap} \cdot \mathrm{Bap})+(\mathrm{Pr} \cdot \mathrm{Br})] /(\mathrm{Bap}+\mathrm{Br})
$$

where: Pap - P content in aboveground parts $[\mathrm{g} / \mathrm{kg} \mathrm{d}$ d.m.], $\mathrm{Pr}$ - P content in the roots [g/kg d.m.], Bap - biomass of aboveground parts [g d.m./pot], $\mathrm{Br}$ - biomass of roots [g d.m./pot].

Amounts of taken up P (P-uptake $[\mathrm{mg} / \mathrm{kg}$ ] were calculated on the basis of the amount of biomass (aboveground parts and roots) of $P$. pratensis and the $\mathrm{P}$ content in biomass (3):

$$
\text { P-uptake }=(\mathrm{BY} \cdot \mathrm{Pc}) / 1000
$$

where: BY - biomass yield [g d.m./pot], Pc - P content in biomass [g d.m./kg].

\section{Statistical analysis}

The experiment was performed in three replicates. The obtained data were compiled with the use of STATISTICA 12.5 (StatSoft Inc.). The mean values of analysed properties were compared using Tukey's multiple comparison test at $p \leq 0.05$. The value of the correlation coefficient $r$ was calculated for selected parameters. Variations in the treatments were determined by calculating the standard deviation $( \pm S D)$.

\section{Results and discussion}

\section{Characteristics of biochars and soil}

Biochars used in the study and collected in Krakow (BC-1), Krzeszowice (BC-2) and Slomniki (BC-3) had different chemical properties, which was conditioned by the origin of sewage sludge (Table 2). Among the tested parameters, the greatest variation concerned the content of trace elements. Significant differentiation between biochars also concerned the determined values of $S_{B E T}$ and $V_{\text {tot }}{ }^{0.99}$. Less variation was found in the values of $\mathrm{pH}$, ash content, and elementary composition of the tested biochars (CHNOS).

As it results from the studies carried out by Manolikaki et al. [19], most biochars produced at 300 and $500{ }^{\circ} \mathrm{C}$ had an alkaline $\mathrm{pH}$. According to Windeatt et al. [20], the $\mathrm{pH}$ values of biochars are generally in the range from 6.1 to 11.6, depending on the feedstock from which they were produced. In our own study, the $\mathrm{pH}$ values of sewage sludge biochars were within the range given by Windeatt et al. [20]. Singh et al. [21] explained that the frequent alkaline character of biochar is due to the carbonate content and the release of alkaline elements such as $\mathrm{Na}, \mathrm{K}, \mathrm{Ca}$, and $\mathrm{Mg}$ during thermal conversion of biomass. As stated by Gai et al. [22] and Jindo et al. [23], the temperature used in the process of 
thermal conversion of organic material greatly affects losses of volatile elements such as $\mathrm{N}$, $\mathrm{O}, \mathrm{H}$, and $\mathrm{C}$. These authors indicated that the temperature increase during pyrolysis results in a greater loss of $\mathrm{H}$ and $\mathrm{O}$ compared to C. However, according to Manolikaki et al. [19], the temperature and type of pyrolysed feedstock are decisive factors for the loss of volatile elements. In addition to volatile elements, the contents of ash and ash components undergo changes during pyrolysis, and their concentration increases [19, 24]. Our results related to the contents of ash and ash components were similar to these obtained by Méndez et al. [25]. The porosity and specific surface area of biochars are important physical properties taking into account the effect of this type of materials on soil properties. Jindo et al. [23] obtained higher values of $S_{B E T}$ compared to these determined in the present study. However, it should be noted that these authors analysed biochars produced from different materials and at higher temperatures of the pyrolysis process.

Selected properties of sewage sludge biochars

Table 2

\begin{tabular}{|c|c|c|c|}
\hline Determination & BC-1 & BC-2 & BC-3 \\
\hline Dry matter $[\%]$ & $96 \pm 8$ & $97 \pm 10$ & $97 \pm 9$ \\
\hline $\mathrm{pH}\left(\mathrm{H}_{2} \mathrm{O}\right)$ & $6.89 \pm 0.08$ & $7.06 \pm 0.04$ & $7.18 \pm 0.04$ \\
\hline Ash [g/kg d.m.] & $692 \pm 13$ & $614 \pm 14$ & $761 \pm 15$ \\
\hline $\mathrm{N}[\%]$ & $2.81 \pm 0.11$ & $3.66 \pm 0.07$ & $2.57 \pm 0.00$ \\
\hline $\mathrm{C}[\%]$ & $19 \pm 0$ & $26 \pm 0$ & $16 \pm 1$ \\
\hline $\mathrm{S}[\%]$ & $2.27 \pm 0.20$ & $0.87 \pm 0.07$ & $0.44 \pm 0.07$ \\
\hline $\mathrm{H}[\%]$ & $2.05 \pm 0.06$ & $2.39 \pm 0.07$ & $1.38 \pm 0.07$ \\
\hline $\mathrm{O}[\%]$ & $4.90 \pm 0.42$ & $5.75 \pm 0.45$ & $1.52 \pm 0.27$ \\
\hline $\mathrm{K}$ [g/kg d.m.] & $4.32 \pm 0.14$ & $3.54 \pm 0.31$ & $3.92 \pm 0.28$ \\
\hline $\mathrm{Mg}$ [g/kg d.m.] & $12.4 \pm 0.3$ & $9.6 \pm 0.3$ & $5.9 \pm 0.3$ \\
\hline $\mathrm{Ca}$ [g/kg d.m.] & $42 \pm 3$ & $65 \pm 2$ & $34 \pm 2$ \\
\hline $\mathrm{Na}$ [g/kg d.m.] & $1.15 \pm 0.04$ & $0.93 \pm 0.04$ & $1.57 \pm 0.09$ \\
\hline $\mathrm{Cu}$ [mg/kg d.m.] & $467 \pm 14$ & $182 \pm 6$ & $100 \pm 6$ \\
\hline $\mathrm{Cd}$ [mg/kg d.m.] & $2.79 \pm 0.09$ & $3.87 \pm 0.05$ & $1.12 \pm 0.04$ \\
\hline $\mathrm{Pb}$ [mg/kg d.m.] & $81 \pm 2$ & $70 \pm 1$ & $22 \pm 1$ \\
\hline $\mathrm{Zn}$ [mg/kg d.m.] & $2321 \pm 30$ & $1436 \pm 26$ & $723 \pm 30$ \\
\hline $\mathrm{Cr}[\mathrm{mg} / \mathrm{kg}$ d.m. $]$ & $586 \pm 10$ & $52 \pm 4$ & $87 \pm 19$ \\
\hline $\mathrm{Ni}$ [mg/kg d.m.] & $89 \pm 4$ & $28 \pm 1$ & $23 \pm 1$ \\
\hline $\mathrm{Mn}$ [mg/kg d.m.] & $515 \pm 8$ & $496 \pm 17$ & $600 \pm 68$ \\
\hline $\mathrm{Fe}[\mathrm{mg} / \mathrm{kg}$ d.m.] & $47895 \pm 551$ & $16304 \pm 569$ & $11610 \pm 802$ \\
\hline$S_{B E T}\left[\mathrm{~m}^{2} / \mathrm{g}\right]$ & 24.9 & 11.9 & 2.2 \\
\hline$V_{\text {tot }}^{0.99}$ & 0.075 & 0.039 & 0.007 \\
\hline
\end{tabular}

Each value represents the mean of three replicates $\pm S D$ (standard deviation), d.m. - dry matter

The soil used in the studies was sandy and acidic and contained $4.20 \mathrm{~g} / \mathrm{kg} \mathrm{d}$.m. of total carbon and $0.87 \mathrm{~g} / \mathrm{kg} \mathrm{d} . \mathrm{m}$. of total nitrogen (Table 1). Before the tests, the total phosphorus content (P-total) in the soil was $0.17 \mathrm{~g} / \mathrm{kg} \mathrm{d}$.m. of soil, while of $\mathrm{P}^{-\mathrm{CaCl}_{2}} 1.54 \mathrm{mg} / \mathrm{kg} \mathrm{d}$.m. of soil. The total contents of the tested trace elements were typical for uncontaminated soils [26].

\section{The content of phosphorus in biochars}

The content of P-total was the highest in BC-1 biochar produced from SS-1 sewage sludge (Table 3). The increase in P-total in BC-1 was over $40 \%$ compared to SS-1. Lower increase in the $\mathrm{P}$ content was noted in $\mathrm{BC}-2$ and $\mathrm{BC}-3$ biochars compared to $\mathrm{BC}-1$ biochar. 
The total $\mathrm{P}$ content in biochar is important for determining its fertilisation potential, whereas the content of $\mathrm{P}-\mathrm{H}_{2} \mathrm{O}$ and $\mathrm{P}-\mathrm{CaCl}_{2}$ informs about the availability of $\mathrm{P}$ for plants [6]. Regardless of the extractant used, the $\mathrm{P}$ content was the highest in $\mathrm{BC}-2$. The share of $\mathrm{P}-\mathrm{H}_{2} \mathrm{O}$ and $\mathrm{P}-\mathrm{CaCl}_{2}$ in P-total in biochars was diverse. The lowest share of $\mathrm{P}-\mathrm{H}_{2} \mathrm{O}$ and $\mathrm{P}-\mathrm{CaCl}_{2}$ in the total phosphorus content was determined for $\mathrm{BC}-1$ biochar.

Results obtained by Atienza-Martinez et al. [27] showed that sewage sludge biochar contains significant resources of $\mathrm{P}$ compounds, which can be a renewable source of this element. These authors suggested that it is possible to completely leach $\mathrm{P}$ from thermally converted sewage sludge.

Table 3

The total and available phosphorus contents in sewage sludge and biochars

\begin{tabular}{|c|c|c|c|c|c|}
\hline Determination & $\begin{array}{c}\text { P-total } \\
\text { [g/kg d.m.] }\end{array}$ & $\begin{array}{c}\mathrm{P}-\mathrm{H}_{2} \mathrm{O} \\
{[\mathrm{mg} / \mathrm{kg} \mathrm{d.m.}]}\end{array}$ & $\begin{array}{c}\text { Share of } \\
\text { P-H } \mathrm{H}_{2} \mathrm{O} \text { in } \\
\text { P-total } \\
{[\%]}\end{array}$ & $\begin{array}{c}\mathrm{P}-\mathrm{CaCl}_{2} \\
\text { [g/kg d.m.] }\end{array}$ & $\begin{array}{c}\text { Share of } \\
\text { P-CaCl }_{2} \text { in } \\
\text { P-total } \\
{[\%]}\end{array}$ \\
\hline SS-1 & $31.8 \pm 0.8$ & $152 \pm 5$ & 0.48 & $81 \pm 3$ & 0.25 \\
\hline SS-2 & $24.1 \pm 0.3$ & $560 \pm 25$ & 2.65 & $167 \pm 16$ & 0.69 \\
\hline SS-3 & $12.7 \pm 0.1$ & $1250 \pm 76$ & 9.84 & $507 \pm 55$ & 3.99 \\
\hline BC-1 & $45.4 \pm 0.7$ & $32 \pm 2$ & 0.07 & $12 \pm 1$ & 0.03 \\
\hline BC-2 & $33.2 \pm 0.7$ & $60 \pm 6$ & 0.18 & $48 \pm 2$ & 0.14 \\
\hline BC-3 & $15.5 \pm 0.8$ & $44 \pm 1$ & 0.28 & $22 \pm 1$ & 0.14 \\
\hline
\end{tabular}

Each value represents the mean of three replicates $\pm S D$ (standard deviation), d.m. - dry matter

However, the process developed by the abovementioned authors requires the use of a very high temperature $\left(900{ }^{\circ} \mathrm{C}\right)$ and then leaching of phosphorus compounds. In our study, the process of thermal conversion of sewage sludge increased the content of P-total, but, at the same time, significantly reduced the contents of $\mathrm{P}-\mathrm{H}_{2} \mathrm{O}$ and $\mathrm{P}-\mathrm{CaCl}_{2}$. Qian and Jiang [3] and Sun et al. [6] argued that the temperature of sewage sludge conversion may significantly affect the total and available $\mathrm{P}$ contents in biochars. Qian and Jiang [3] indicated that pyrolysis of sewage sludge at $400-600{ }^{\circ} \mathrm{C}$ results in a greater content of $\mathrm{P}$ compounds available for plants in the short term, while, at $600-800{ }^{\circ} \mathrm{C}$, it results in the formation of phosphorus compounds available for plants in the long term. Also Mackay et al. [28] showed that thermally converted SS contained a greater proportion of $\mathrm{P}$ within recalcitrant pools. According to Qian and Jiang [3] and Dai et al. [29], thermal conversion of organic materials causes the formation of $\mathrm{P}$ compounds which are less soluble. These authors admitted that the presence of multivalent metal cations such as $\mathrm{Al}^{3+}, \mathrm{Fe}^{3+}, \mathrm{Ca}^{2+}$ and $\mathrm{Mg}^{2+}$ in biochars promotes the formation of poorly soluble $\mathrm{P}$ compounds.

\section{Soil pH, electrical conductivity $(E C)$ and total carbon content}

The $\mathrm{pH}$ values determined in the suspension of soil and $\mathrm{KCl}$ solution depended on the type and amount of the biochar used (Table 4). In addition to $\mathrm{BC}-1$ biochar, even the smallest addition of $\mathrm{BC}-2$ and $\mathrm{BC}-3$ biochars to the soil significantly reduced the $\mathrm{pH}$ value compared to the control soil. When analysing the largest biochar additions it can be concluded that compared to the control, the lowest $\mathrm{pH}$ increase (by $0.51 \mathrm{pH}$ units) was present after the application of $\mathrm{BC}-1$ biochar, and the highest (by $1.44 \mathrm{pH}$ units), after the application of BC-3 biochar. 
Selected chemical properties of soil after biochar application

\begin{tabular}{|c|c|c|c|}
\hline Treatment & $\mathbf{p H}(\mathbf{K C l})$ & $\begin{array}{c}\boldsymbol{E C} \\
{[\boldsymbol{\mu S} / \mathbf{c m}]}\end{array}$ & $\begin{array}{c}\text { C-total } \\
{[\mathbf{g} / \mathbf{k g ~ d . m} .]}\end{array}$ \\
\hline Soil & $4.65^{\mathrm{a}} \pm 0.03$ & $27.3^{\mathrm{a}} \pm 0.8$ & $4.53^{\mathrm{a}} \pm 0.13$ \\
\hline Soil + 0.5\% BC-1 & $4.77^{\mathrm{ab}} \pm 0.01$ & $102^{\mathrm{b}} \pm 11$ & $4.76^{\mathrm{a}} \pm 0.04$ \\
\hline Soil + 1\% BC-1 & $4.92^{\mathrm{bc}} \pm 0.03$ & $273^{\mathrm{c}} \pm 35$ & $5.44^{\mathrm{ab}} \pm 0.43$ \\
\hline Soil + 2\% BC-1 & $5.16^{\mathrm{cd}} \pm 0.04$ & $386^{\mathrm{c}} \pm 45$ & $5.99^{\mathrm{cc}} \pm 0.57$ \\
\hline Soil + 0.5\% BC-2 & $4.96^{\mathrm{bc}} \pm 0.05$ & $52.3^{\mathrm{a}} \pm 2.6$ & $4.76^{\mathrm{a}} \pm 0.31$ \\
\hline Soil + 1\% BC-2 & $5.26^{\mathrm{de}} \pm 0.07$ & $52.1^{\mathrm{a}} \pm 2.6$ & $5.18^{\mathrm{ab}} \pm 0.30$ \\
\hline Soil + 2\% BC-2 & $5.71^{\mathrm{f}} \pm 0.09$ & $64.2^{\mathrm{a}} \pm 4.1$ & $5.56^{\mathrm{bc}} \pm 0.38$ \\
\hline Soil + 0.5\% BC-3 & $5.05^{\mathrm{cd}} \pm 0.21$ & $43^{\mathrm{a}} \pm 10$ & $4.61^{\mathrm{a}} \pm 0.20$ \\
\hline Soil + 1\% BC-3 & $5.45^{\mathrm{a}} \pm 0.10$ & $49.3^{\mathrm{a}} \pm 3.5$ & $5.38^{\mathrm{ab}} \pm 0.53$ \\
\hline Soil +2\% BC-3 & $6.09^{\mathrm{g}} \pm 0.07$ & $64^{\mathrm{a}} \pm 11$ & $6.58^{\mathrm{c}} \pm 0.34$ \\
\hline
\end{tabular}

Each value represents the mean of three replicates $\pm S D$ (standard deviation), d.m. - dry matter. The different letters within a column indicate a significant difference at $p \leq 0.05$ according to Tukey's multiple range tests, factor: type of biochar $\times$ dose

The beneficial effect of biochars used on the soil $\mathrm{pH}$ results from the significant $\mathrm{Ca}$ and $\mathrm{Mg}$ contents in these biochars (Table 2). The deacidifying effect of biochars demonstrated in the present study is also confirmed by the results obtained by Nigussie et al. [30] and Kloss et al. [24]. These authors proved the increase of $\mathrm{pH}$ values of soils used in their studies after the application of biochars produced from various materials.

The value of electrical conductivity in the soil of treatments in which biochars were applied was higher compared to the $E C$ value determined in the control soil (Table 4). However, no significant increase in the parameter value was proved in the soil of treatments with BC-2 and BC-3 biochars applied, regardless of the dose. On the other hand, compared to both the control treatment and all other treatments of the experiment, the $E C$ value was significantly higher in all treatments with $\mathrm{BC}-1$ biochar applied. Compared to electrical conductivity values identified for treatments in which BC-2 and BC-3 biochars were applied, $E C$ values were on average 2-, 5- and 6-times higher after applying 0.5, 1 and $2 \%$ doses of BC-1.

Also Kloss et al. [24] noted a significant increase in electrical conductivity in soil after the use of biochar produced from maize stalk. According to Solaiman and Anawar [31], the biochar application to soil does not have to be identified with an increase in the $E C$ value. These authors stated that, due to its sorption capacity, biochar can, under soil conditions, reduce the content of salts easily soluble in soil solution.

The $\mathrm{C}$ content in the soil increased significantly only after introducing the largest, $2 \%$ addition of biochars (Table 4). The increase in C-total content in treatments with $2 \%$ addition of BC-1, BC-2, and BC-3 biochars applied was 32, 22, and $45 \%$, respectively, compared to the control treatment.

As stated by Hernandez-Sariano et al. [32], the use of biochar can contribute to C storage in soil. According to these authors, upon addition of biochar, there is a spatial reorganisation of $\mathrm{C}$ within soil particles, and soil respiration is lower in biochar-amended soils than in residue-amended soils. According to Jiang et al. [33], causes of higher $\mathrm{C}$ content in soil after application of biochar compared to thermally unconverted materials should be mainly sought in the material's resistance to microbial decomposition. 


\section{Phosphorus content and availability in soil}

The content of P-total in the soil increased with the increase of BC-introduced, regardless of the type of $\mathrm{BC}$. A significant positive relationship was found between the amount of P-introduced into the soil with $\mathrm{BC}$ and the P-total content in soil $(r=0.736$; $p \leq 0.05)$. The highest contents of P-total were found in treatments amended with $\mathrm{BC}-1$ (Table 5). The increase in P-total compared to the control treatment was, depending on the dose: for $\mathrm{BC}-1$ from 64 to $296 \%$, for $\mathrm{BC}-2$ from 24 to $78 \%$, and for $\mathrm{BC}-3$ from 45 to $177 \%$.

The $\mathrm{P}-\mathrm{CaCl}_{2}$ content in soil depended on the type and amount of biochar (Table 5). A significant increase in the content of $\mathrm{P}-\mathrm{CaCl}_{2}$ compared to the control treatment was noted in the soil of treatments where 1 and $2 \%$ additions of BC-2 and BC-3 were applied. Compared to the control, the increase in $\mathrm{P}-\mathrm{CaCl}_{2}$ content in these treatments was 65 and $236 \%$ as well as 119 and $290 \%$, respectively. It should be noted that a significant effect on the content of $\mathrm{P}_{-\mathrm{CaCl}_{2}}$ in soil had: soil $\mathrm{pH}(r=0.826 ; p \leq 0.05)$, the content of Ca-exch. $(r=0.712 ; p \leq 0.05)$ and of Mg-exch. $(r=0.389 ; p \leq 0.05)$. However, we did not prove a significant effect of the amount of P-introduced with $\mathrm{BC}$ and the content of Fe-ox. and Al-ox. on the content of $\mathrm{P}-\mathrm{CaCl}_{2}$ in soil. The contents of $\mathrm{Ca}$-exch. and $\mathrm{Mg}$-exch. increased in the soil into which biochars were introduced, and such increase was relative to the dose used. Except for treatments with BC-1, the Fe-ox. content decreased with the increase of $\mathrm{BC}$ dose, while the content of Al-ox. showed no targeted changes (Table 6).

Table 5

Total (P-total) and bioavailable $\left(\mathrm{P}-\mathrm{CaCl}_{2}\right) \mathrm{P}$ contents in soil; increments of contents of both forms compared to these contents in control soil $($ Soil $=100)$

\begin{tabular}{|c|c|c|c|c|}
\hline Treatment & $\begin{array}{c}\text { P-total } \\
\text { [mg/kg d.m.] }\end{array}$ & $\begin{array}{c}\text { Increment to } \\
\text { control soil } \\
{[\%]}\end{array}$ & $\begin{array}{c}\mathrm{P}-\mathrm{CaCl}_{2} \\
\text { [mg/kg d.m.] }\end{array}$ & $\begin{array}{c}\text { Increment to } \\
\text { control soil } \\
{[\%]}\end{array}$ \\
\hline Soil & $182^{\mathrm{a}} \pm 5$ & 100 & $1.25^{\mathrm{a}} \pm 0.20$ & 100 \\
\hline Soil + $0.5 \%$ BC-1 & $300^{\mathrm{ab}} \pm 25$ & 165 & $1.56^{\mathrm{ab}} \pm 0.41$ & 125 \\
\hline Soil + $1 \%$ BC-1 & $407^{\mathrm{bc}} \pm 7$ & 224 & $1.74^{\mathrm{ab}} \pm 0.16$ & 139 \\
\hline Soil + $2 \%$ BC-1 & $722^{d} \pm 99$ & 397 & $1.94^{\mathrm{ab}} \pm 0.23$ & 155 \\
\hline Soil + $0.5 \%$ BC-2 & $227^{\mathrm{a}} \pm 7$ & 125 & $1.64^{\mathrm{ab}} \pm 0.05$ & 131 \\
\hline Soil + $1 \%$ BC-2 & $261^{\mathrm{ab}} \pm 10$ & 143 & $2.07^{\mathrm{b}} \pm 0.30$ & 163 \\
\hline Soil + $2 \%$ BC-2 & $324^{\mathrm{abc}} \pm 16$ & 178 & $4.12^{\mathrm{c}} \pm 0.44$ & 330 \\
\hline Soil + $0.5 \%$ BC-3 & $265^{\mathrm{ab}} \pm 16$ & 146 & $1.78^{\mathrm{ab}} \pm 0.15$ & 142 \\
\hline Soil + $1 \%$ BC-3 & $347^{\mathrm{abc}} \pm 20$ & 191 & $2.74^{\mathrm{b}} \pm 0.17$ & 219 \\
\hline Soil $+2 \%$ BC-3 & $505^{\mathrm{cd}} \pm 3$ & 277 & $4.88^{\mathrm{c}} \pm 0.56$ & 390 \\
\hline
\end{tabular}

Each value represents the mean of three replicates $\pm S D$ (standard deviation), d.m. - dry matter. The different letters within a column indicate a significant difference at $p \leq 0.05$ according to Tukey's multiple range tests, factor: type of biochar $\times$ dose

Dai et al. [5] argued that biochar is characterised by lower release of $\mathrm{P}$ after introduction into the soil, which influences its long-lasting effect in providing this component to plants. Therefore, the application of biochar to the soil, especially the one produced from materials rich in $\mathrm{P}$, will increase the total contents of this element, which was also confirmed in our own study. At the same time, it should be emphasised that the content of persistent $\mathrm{P}$ bonds in biochars will also be crucial in reducing the loss of this component from the soil [5]. The relatively low solubility of P compounds in the soil has, on the one hand, the environmental dimension, because it limits the losses of $\mathrm{P}$ and, on the 
other, the fertilisation dimension, because it provides a long-term source of this component for plants. An essential element affecting the available $\mathrm{P}$ content in the soil are soil properties, including its $\mathrm{pH}$, which is confirmed in the present study and in the study of Dai et al. [3].

Table 6

The contents of Ca-exch., Mg-exch., Al-ox., and Fe ox. in soil

\begin{tabular}{|c|c|c|c|c|}
\hline \multirow{2}{*}{ Treatment } & Ca-exch. & Mg-exch. & Fe-ox. & Al-ox. \\
\cline { 2 - 5 } & \multicolumn{4}{|c|}{ [mg/kg d.m.] } \\
\hline Soil & $108^{\mathrm{a}} \pm 5$ & $13.2^{\mathrm{a}} \pm 0.7$ & $758^{\mathrm{a}} \pm 95$ & $498^{\mathrm{a}} \pm 98$ \\
\hline Soil + 0.5\% BC-1 & $175^{\mathrm{b}} \pm 6$ & $27.9^{\mathrm{bc}} \pm 1.9$ & $1122^{\mathrm{bc}} \pm 10$ & $567^{\mathrm{a}} \pm 33$ \\
\hline Soil + 1\% BC-1 & $255^{\mathrm{def}} \pm 30$ & $42.7^{\mathrm{de}} \pm 0.4$ & $1396^{\mathrm{c}} \pm 64$ & $601^{\mathrm{a}} \pm 93$ \\
\hline Soil + 2\% BC-1 & $275^{\mathrm{f}} \pm 4$ & $67.0^{\mathrm{f}} \pm 3.1$ & $1834^{\mathrm{d}} \pm 35$ & $623^{\mathrm{a}} \pm 66$ \\
\hline Soil + 0.5\% BC-2 & $186^{\mathrm{bc}} \pm 8$ & $24.0^{\mathrm{ab}} \pm 1.8$ & $1152^{\mathrm{bc}} \pm 24$ & $644^{\mathrm{a}} \pm 49$ \\
\hline Soil + \% BC-2 & $229^{\mathrm{de}} \pm 16$ & $26.2^{\mathrm{bc}} \pm 3.4$ & $974^{\mathrm{ab}} \pm 74$ & $653^{\mathrm{a}} \pm 59$ \\
\hline Soil + 2\% BC-2 & $265^{\mathrm{ef}} \pm 7$ & $36.8^{\mathrm{cd}} \pm 1.1$ & $912^{\mathrm{ab}} \pm 80$ & $563^{\mathrm{a}} \pm 75$ \\
\hline Soil + 0.5\% BC-3 & $219^{\mathrm{cd}} \pm 8$ & $23.7^{\mathrm{ab}} \pm 3.5$ & $1098^{\mathrm{abc}} \pm 92$ & $680^{\mathrm{a}} \pm 96$ \\
\hline Soil + 1\% BC-3 & $255^{\mathrm{def}} \pm 2$ & $27.9^{\mathrm{bc}} \pm 6.0$ & $1044^{\mathrm{abc}} \pm 65$ & $640^{\mathrm{a}} \pm 98$ \\
\hline Soil +2\% BC-3 & $361^{\mathrm{g}} \pm 24$ & $50.6^{\mathrm{e}} \pm 8.6$ & $909^{\mathrm{ab}} \pm 46$ & $619^{\mathrm{a}} \pm 77$ \\
\hline
\end{tabular}

Each value represents the mean of three replicates $\pm S D$ (standard deviation), d.m. - dry matter. The different letters within a column indicate a significant difference at $p \leq 0.05$ according to Tukey's multiple range tests, factor: type of biochar $\times$ dose

As it was mentioned before, biochar application to the soil usually reduces soil acidification $[34,35]$, and this, in turn, leads to a reduction in the activity of metal ions such as $\mathrm{Al}^{3+}$ and $\mathrm{Fe}^{3+}$ which form sparingly soluble compounds with $\mathrm{P}$. On the other hand, the content of $\mathrm{Ca}^{2+}$ and $\mathrm{Mg}^{2+}$ ions is increased, which also can form sparingly soluble compounds with $\mathrm{P}$. In our study, a significant relationship between $\mathrm{P}-\mathrm{CaCl}_{2}$ and exchangeable $\mathrm{Ca}^{2+}$ and $\mathrm{Mg}^{2+}$ ions was observed. The soil of treatments with the highest $\mathrm{P}-\mathrm{CaCl}_{2}$ content also had the highest $\mathrm{pH}$ values. It should also be mentioned that despite the largest $\mathrm{P}$ load introduced into the soil from $\mathrm{BC}-1$ biochar, no significant increase of $\mathrm{P}-\mathrm{CaCl}_{2}$ was identified even after the application of the largest dose of this biochar. This was due to the relatively low effect of $\mathrm{BC}-1$ on soil $\mathrm{pH}$, as well as the lowest available $\mathrm{P}$ content in this material (Table 3). According to Murphy and Stevens [36] and Mukherjee et al. [37], the increase in the $\mathrm{pH}$ value for acidic soils translates into an increase in the number of negative charges of soil colloids, leading to an increase in anionic repulsion and reduction of sorption of phosphate anions. As stated by Hong and Lu [38] and Martinez et al. [39], the addition of biochar to the soil favours $\mathrm{P}$ desorption, which leads to the element increase in soil solution. In our study, this relationship was noted for BC-2 and BC-3 biochars used at 1 and $2 \%$ doses. The obtained results and the results presented by other authors show that there is a large discrepancy regarding the biochar's effect on the available $\mathrm{P}$ content in soil [39-41].

\section{The amounts of $P$. pratensis biomass}

In the present study, the largest total amount of $P$. pratensis biomass (aboveground parts and roots) was collected in the treatment with $2 \%$ addition of $\mathrm{BC}-1$ biochar introduced (Fig. 1). 


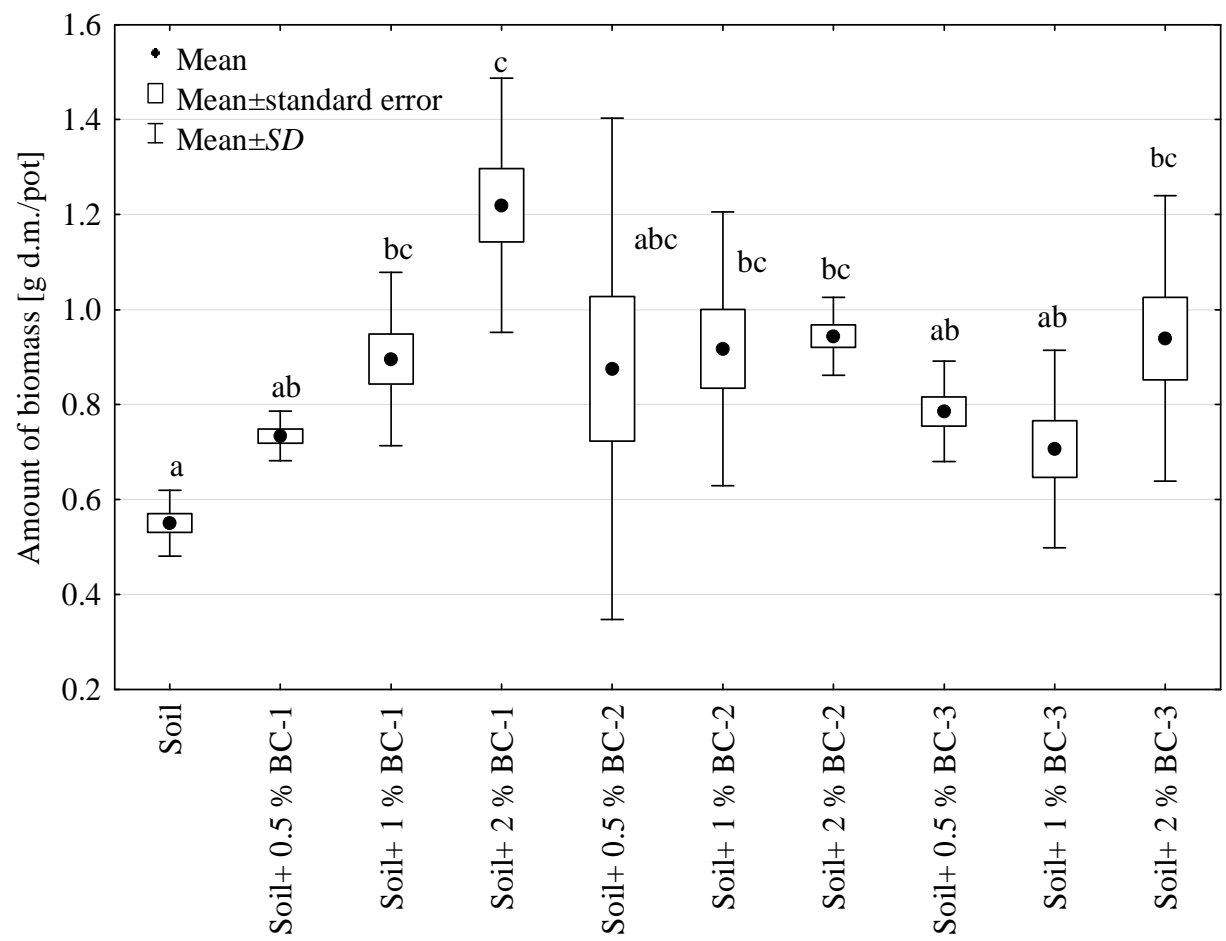

Fig. 1. The amount of biomass $P$. pratensis harvested. Each value represents the mean of 3 replicates \pm standard deviation. The different letters indicate a significant difference at $p<0.05$, according to the Tukey multiple range test (factor: type of biochar $\times$ dose)

In treatments amended with $\mathrm{BC}-1$ biochar, the amounts of biomass obtained increased in proportion to the dose of biochar applied. A similar relationship, although with a smaller biomass amount, was noted after the use of BC-2 biochar. The application of $1 \%$ dose of BC-3 biochar decreased the amount of $P$. pratensis biomass compared to treatments with 0.5 and $2 \%$ additions of this material.

The study results published so far on biochar's effect on crop yielding are not unambiguous. According to Manolikaki et al. [19], the introduction of biochar into slightly acidic soil increased the amount of pant biomass. This relationship was not identified by these authors for alkaline soil. Borchard et al. [42] reported about a negative effect of biochar on maize growth. Also Kloss et al. [24] indicated a reduction in mustard and barley yield after the use of biochar. In the present study, no negative effect of the biochars used on the amount of $P$. pratensis biomass was observed. When it comes to plant yielding, the physical properties of the soil, especially its structure are very important, just as deacidifying properties of biochar and nutrients introduced with it [43]. This aspect is particularly important in the case of sandy soils. The improvement of soil physical properties after the application of biochar concerns, inter alia, greater soil capacity for retaining water and nutrients in the root zone. 


\section{The contents and amounts of phosphorus taken up by $P$. pratensis biomass}

The weighted average content of phosphorus in P. pratensis biomass (P-content) and the amounts of $\mathrm{P}$ taken up (P-uptake) are shown in Table 7.

Table 7

P. pratensis weighted average (above-ground parts and roots) content of phosphorus (P-content) and total uptake of $\mathrm{P}$ with biomass (P-uptake)

\begin{tabular}{|c|c|c|}
\hline Treatment & $\begin{array}{c}\text { P-content } \\
\text { [g/kg d.m.] }\end{array}$ & $\begin{array}{c}\text { P-uptake } \\
{[\mathbf{m g} / \mathbf{p o t}]}\end{array}$ \\
\hline Soil & $2.77^{\mathrm{a}} \pm 0.34$ & $1.52^{\mathrm{a}} \pm 0.08$ \\
\hline Soil + 0.5.\% BC-1 & $4.35^{\mathrm{bc}} \pm 0.43$ & $3.20^{\mathrm{bc}} \pm 0.40$ \\
\hline Soil + $1 . \%$ BC-1 & $5.29^{\mathrm{c}} \pm 0.68$ & $4.74^{\mathrm{cd}} \pm 0.83$ \\
\hline Soil + 2.\% BC-1 & $4.08^{\mathrm{bc}} \pm 0.84$ & $4.98^{\mathrm{d}} \pm 1.36$ \\
\hline Soil $+0.5 . \%$ BC-2 & $3.11^{\mathrm{b}} \pm 0.63$ & $2.62^{\mathrm{b}} \pm 0.25$ \\
\hline Soil $+1 . \%$ BC-2 & $3.89^{\mathrm{bc}} \pm 0.83$ & $3.49^{\mathrm{bcd}} \pm 0.19$ \\
\hline Soil $+2 \%$ BC-2 & $3.82^{\mathrm{bc}} \pm 0.24$ & $3.60^{\mathrm{bcd}} \pm 0.24$ \\
\hline Soil $+0.5 \%$ BC-3 & $3.41^{\mathrm{b}} \pm 019$ & $2.67^{\mathrm{b}} \pm 0.05$ \\
\hline Soil $+1 . \%$ BC-3 & $4.23^{\mathrm{bc}} \pm 0.52$ & $2.96^{\mathrm{bc}} \pm 0.29$ \\
\hline Soil $+2 \%$ BC-3 & $4.58^{\mathrm{bc}} \pm 0.35$ & $4.33^{\mathrm{bcd}} \pm 0.98$ \\
\hline
\end{tabular}

Each value represents the mean of three replicates $\pm S D$ (standard deviation), d.m. - dry matter. The different letters within a column indicate a significant difference at $p \leq 0.05$ according to Tukey's multiple range tests, factor: type of biochar $\times$ dose

Significant $(p \leq 0.05)$ increase in the $\mathrm{P}$ content in plant biomass was noted in all treatments compared to the control. After the use of $2 \%$ doses of BC-1 and BC-2 biochars, the $\mathrm{P}$ content in plant biomass was lower than its contents determined in plants collected in treatments with $1 \%$ addition of both biochars. This was not the situation in the case of BC-3 biochar.

Regardless of the type of biochar applied, the highest amount of P-uptake was determined in treatments where the greatest addition of BC (2\%) was introduced into the soil.

This situation resulted from the fact that the highest amount of $P$. pratensis biomass was collected in these treatments. It should be noted that the amount of P-introduced with biochar had a significant effect on P-uptake by plant biomass $(r=0.726 ; p \leq 0.05)$.

The studies carried out so far on the effect of biochar on the availability and uptake of phosphorus are divergent. The increased availability of $\mathrm{P}$ for plants after the introduction of biochar in alkaline environment was discovered by Vaccari et al. [44], in acidic environment by Kloss et al. [24], while the studies of Gaskin et al. [45] did not show any differences in $\mathrm{P}$ availability in soil after the biochar application. According to Faria et al. [46], the application of sewage sludge biochars to the soil affects its chemical properties, including increases soil fertility in P. These authors also stated that sewage sludge biochar could replace the use of mineral fertilisers containing P. Biederman and Harpole [47] showed a substantial increase in $\mathrm{P}$ concentration in plant tissues after application of biochar. Also Shen et al. [48] reported that the introduction of biochar into the soil with $\mathrm{P}$ deficiency increased its amount taken up by plants. Nigussie et al. [30] identified a significant increase in P uptake, and Lehmann and Joseph [35] increase in P content in plants after biochar application. The authors quoted above explained this increase of $\mathrm{P}$ content in plant biomass mainly with a high $\mathrm{P}$ content in biochar. In our own study, also a significant positive relationship between $\mathrm{P}$-uptake by $P$. pratensis and the amount of 
P-introduced with BC into the soil was demonstrated. However, our results did not confirm a significant relationship between the content of $\mathrm{P}_{-} \mathrm{CaCl}_{2}$ in the soil and the amount of $\mathrm{P}$ taken up by $P$. pratensis.

\section{Conclusions}

The conversion of sewage sludge in the pyrolysis process reduces the contents of $\mathrm{P}-\mathrm{H}_{2} \mathrm{O}$ and $\mathrm{P}-\mathrm{CaCl}_{2}$. A significant positive relationship was found between the amount of phosphorus introduced into the soil with $\mathrm{BC}$ and the total contents of this element in the soil. A significant increase in the content of $\mathrm{P}-\mathrm{CaCl}_{2}$ compared to the control treatment was noted in the soil of treatments where 1 and $2 \%$ additions of $\mathrm{BC}-2$ and $\mathrm{BC}-3$ were applied. The content of $\mathrm{P}-\mathrm{CaCl}_{2}$ in soil was greatly affected by $\mathrm{pH}$ and the contents of $\mathrm{Mg}$-exch. and $\mathrm{Ca}$-exch. No significant effect of the amount of P-introduced with $\mathrm{BC}$ and the contents of Al-ox. and Fe-ox. on the content of $\mathrm{P}_{-} \mathrm{CaCl}_{2}$ in soil was proved. Significant increase in the phosphorus content in plant biomass was noted in all treatments with the addition of sewage sludge biochar compared to the control. Regardless of the type of biochar, the highest amount of P-uptake was determined in treatments where the greatest addition of $\mathrm{BC}(2 \%)$ was introduced into the soil.

\section{Acknowledgements}

The research was financed by the Ministry of Science and Higher Education of the Republic of Poland.

\section{References}

[1] European Commission 2008. European Commission, environmental, economic and social impacts of the use of sewage sludge on land. Final report part I: Overview report. http://www.ec.europa.eu/environment/ archives/waste/sludge/pdf/part_i_report.pdf.

[2] Błaszczyk K, Krzyśko-Łupicka T. Microbiological and physico-chemical composition of sewage sludge derived from the food industry. Chem Didact Ecol Metrol. 2013;18(1-2):89-95. DOI: 10.2478/cdem-2013-0021.

[3] Qian T, Jiang H. Migration of phosphorus in sewage sludge during different thermal treatment processes. ACS Sustainable Chem Eng. 2014;2(6):1411-1419. DOI: 10.1021/sc400476j.

[4] European Commission. Communication from the commission to European Parlament, the council, the European economic and social committee and the committee of the regions, on the 2017 list of Critical Raw Materials for the UE, COM (2017) 490 final. https://www.ec.europa.eu/transparency/regdoc/rep/1/2017/EN/ COM-2017-490-F1-EN-MAIN-PART-1.PDF.

[5] Dai L, Li H, Tan F, Zhu N, He M, Hu G. Biochar: a potential route for recycling of phosphorus in agricultural residues. Bioenergy. 2016;8:852-858. DOI: 10.1111/gcbb.12365.

[6] Sun D, Hale L, Kar G, Soolanayakanahally R, Adl S. Phosphorus recovery and reuse by pyrolysis: Applications for agriculture and environment. Chemosphere. 2018;194:682-691. DOI: 10.1016/j.chemosphere.2017.12.035.

[7] European Biochar Certificate. Guidelines for a sustainable production of biochar. Arbaz, Switzerland: EBC, European Biochar Foundation. 2012. http://www.european-biochar.org/biochar/media/doc/ ebc-guidelines.pdf.

[8] Arif M, Ilyas M, Riaz M, Ali K, Shah K, Ul Haq I, et al. Biochar improves phosphorus use efficiency of organic-inorganic fertilizers, maize-wheat productivity and soil quality in a low fertility alkaline soil. Field Crops Res. 2017;214:25-37. DOI: 10.1016/j.fcr.2017.08.018.

[9] Novak JM, Busscher WJ, Laird DL, Ahmedna M, Watts DW, Niandou MAS. Impact of biochar amendment on fertility of a Southeastern Coastal plain soil. Soil Sci. 2009;174:105-112. DOI: 10.1097/SS.0b013e3181981d9a.

[10] Sandeep K, Ebhin MR, Lal R. Biochar preparation from Parthenium hysterophorus and its potential use in soil application. Ecol Eng. 2013;55:67-72. DOI: 10.1016/j.ecoleng.2013.02.011. 
[11] Prendergast-Mille, MT, Duvall M, Sohi SP. Biochar-root interactions are mediated by biochar nutrient content and impacts on soil nutrient availability. Eur J Soil Sci. 2014;65:173-185. DOI: 10.1111/ejss.12079.

[12] IBI. Standardized Product Definition and Product Testing Guidelines for Biochar that Is Used in Soil. IBI-STD-2.1.https://www.biochar-international.org/wpcontent/uploads/2018/04/IBI_Biochar_Standards_V2.1_Final.pdf.

[13] Jindo K, Suto K, Matsumoto K, Garcia C, Sonoki T, Sanchez-Monedero MA. Chemical and biochemical characterisation of biochar-blended composts prepared from poultry manure. Bioresour Technol. 2012;110:396-404. DOI: 10.1016/j.biortech.2012.01.120.

[14] Oleszczuk N, Castro JT, da Silva MM, Korn Md, Welz B, Vale MG. Method development for the determination of manganese, cobalt and copper in green coffee comparing direct solid sampling electrothermal atomic absorption spectrometry and inductively coupled plasma optical emission spectrometry. Talanta. 2007;73(5):862-869. DOI: 10.1016/j.talanta.2007.05.005.

[15] Barret EP, Joyner LG, Halenda PH. The determination of pore volume and area distributions in porous substances. I. Computations from nitrogen isotherms. J Amer Chem Soc. 1951;73(1):373-380. DOI: 10.1021/ja01145a126.

[16] Rayment GE, Higginson FR. Australian Laboratory Handbook of Soil and Water Chemical Methods. Melbourne: Inkata Press; 1992. ISBN: 0909605688.

[17] Blakemore LC, Searle PL, Daly BK. Methods for chemical analysis of soils. Lower Hutt, New Zealand: Soil Bureau, Pub. Department of Scientific and Industrial Research.; 1987; 102. DOI: 10.7931/DL1-SBSR-10A.

[18] Houba VJG, Temminghoff EJM, Gaikhorst GA, Van Vark W. Soil analysis procedures using $0.01 \mathrm{M}$ calcium chloride as extractation reagent. Comm Soil Sci Plant Anal. 2000;31(9-10):1299-1396. DOI: $10.1080 / 00103620009370514$.

[19] Manolikaki II, Mangolis A, Diamadopulos E. The impact of biochars prepared from agricultural residues on phosporus relese and availability in two fertile soils. J Environ Manage. 2016;181:536-543. DOI: 10.1016/j.jenvman.2016.07.012.

[20] Windeatt JH, Ross AB, Williams PT, Forster PM, Nahil MA, Singh S. Characteristics of biochars from crop residues: potential for carbon sequestration and soil amendment. J Environ Manage. 2014;146:189-197. DOI: 10.1016/j.jenvman.2014.08.003.

[21] Singh R, Babu JN, Kumar R, Srivastava P, Singh P, Raghubanshi AS. Multifaceted application of crop residue biochar as a tool for sustainable agriculture: an ecological perspective. Ecol Eng. 2015;77:324-347. DOI: 10.1016/j.ecoleng.2015.01.011.

[22] Gai X, Wang H, Liu J, Zhai L, Liu S, Ren T, Liu H. Effect of feedstock and pyrolysis temperature on biochar adsorption of ammonium and nitrate. PLoS One. 2014;9(12):1-19. DOI: 10.1371/journal.pone.0113888.

[23] Jindo K, Mizumoto H, Sawada Y, Sanchez-Monedero MA, Sonoki T. Physical and chemical characterization of biochars derived from different agricultural residues. Biogeosciences. 2014;11(23):6613-6621. DOI: 10.5194/bg-11-6613-2014.

[24] Kloss S, Zehetner F, Wimmer B, Buecker J, Rempt F, Soja G. Biochar application to temperate soils: effects on soil fertility and crop growth under greenhouse conditions. J Plant Nutr Soil Sci. 2014;177:3-15. DOI: 10.1002/jpln.201200282.

[25] Méndez A, Gomez A, Paz-Ferreiro J, Gasco G. Effects of sewage sludge biochar on plant metal availability after application to a Mediterranean soil. Chemosphere. 2012;89:1354-1359. DOI: 10.1016/j.chemosphere.2012.05.092.

[26] Tóth G, Hermann T, Da Silva MR, Montanarella L. Heavy metals in agricultural soils of the European Union with implications for food safety. Environ Int. 2016;88:299-309. DOI: 10.1016/j.envint.2015.12.017.

[27] Atienza-Martinez M, Gea G, Arauzo J, Kersten SRA, Kootstra MJ. Phosphorus recovery from sewage sludge char ash. Biomass Bioenergy. 2014;65:42-50. DOI: 10.1016/j.biombioe.2014.03.058.

[28] Mackay JE, Cavagnaro TR, Jakobsen I, Macdonald LM, Gronlund M, Thomsen TP, et al. Evaluation of phosphorus in thermally converted sewage sludge: $\mathrm{P}$ pools and availability to wheat. Plant Soil. 2017;418(1-2):307-317. DOI: 10.1007/s11104-017-3298-6.

[29] Dai L, Tan F, Wu B, He M, Wang W, Tang, W, et al. Immobilization of phosphorus in cow manure during hydrothermal carbonization. J Environ Manage. 2015;157:49-53. DOI: 10.1016/j.jenvman.2015.04.009.

[30] Nigussie A, Kissi E, Misganaw M, Ambaw G. Effect of biochar application on soil properties and nutrient uptake of lettuces (Lactuca sativa) grown in chromium polluted soils. American-Eurasian J Agric Environ Sci. 2012;12(3):369-376. https://www.pdfs.semanticscholar.org/ffb5/ e16d49f0b49debdd7fa3f874c4a25d28ad44.pdf.

[31] Solaiman ZN, Anawar HM. Application of biochors for soil constraints: challenge and solutions. Pedosphere. 2015;25(5):631-638. DOI: 10.1016/S1002-0160(15)30044-8. 
[32] Hernandez-Sariano MC, Kerré B, Kopittke PM, Horemans B, Smolders E. Biochar affect carbon composition and stability in soil: a combined spectroscopy-microscopy study. Sci Rep. 2016;6:1-13. DOI: $10.1038 /$ srep25127.

[33] Jiang X, Haddix ML, Cotrufo FM. Interactions between biochar and soil organic carbon decomposition: Effects of nitrogen and low molecular weight carbon compound addition. Soil Biol Biochem. 2016;100:92-101. DOI: 10.1016/j.soilbio.2016.05.020.

[34] Yuan JH, Xu RK, Qian W, Wang RH. Comparison of the ameliorating effects on an acidic ultisol between four crop straws and their biochars. J Soils Sedim. 2011;11:741-750. DOI: 10.1007/s11368-011-0365-0.

[35] Lehmann J, Joseph S, editors. Biochar for Environmental Management. Science, Technology and Implementation. 2nd Ed. London and New York: Taylor Francis Group; 2015; 944. ISBN: 9780415704151.

[36] Murphy PNC, Stevens RJ. Lime and gypsum as Skurce measures to decrease phosphorus loss from soils to water. Water Air Soil Pollut. 2010;212:101-111. DOI: 10.1007/s11270-010-0325-0.

[37] Mukherjee A, Zimmerman AR, Harris W. Surface chemistry variations among a series of laboratory produced biochars. Geoderma. 2011;163:247-255. DOI: 10.1016/j.geoderma.2011.04.021.

[38] Hong C, Lu S. Does biochar affect the availability and chemical fraction of phosphate in soil? Environ Sci Pollut Res Int. 2018;25(9):8725-8734. DOI: 10.1007/s11356-018-1219-8.

[39] Martínez C, José M, España A, César J, Díaz V. Effect of Eucalyptus globullus biochar addition on the availability of phosphorus in acidic soil. Agron Colomb. 2017;35(1):75-81. DOI: 10.15446/agron.colomb.v35n1.58671

[40] Gao S, DeLuca TH, Cleveland CC. Biochar additions alter phosphorus and nitrogen availability in agricultural ecosystems: A meta-analysis. Sci Total Environ. 2019;654(1):463-472. DOI: 10.1016/j.scitotenv.2018.11.124.

[41] Tian X, Li C, Zhang M, Wan Y, Xie Z, Chen B, et al. Biochar derived from corn straw affected availability and distribution of soil nutrients and cotton yield. PLoS ONE. 2018;13(1):1-19. DOI: 10.1371/journal.pone.0189924.

[42] Borchard N, Siemens J, Ladd B, Möller A, Amelung W. Application of biochars to sandy and silty soil failed to increase maize yield under common agricultural practice. Soil Tillage Res. 2014;144:184-194. DOI: 10.1016/j.still.2014.07.016.

[43] Jeffery S, Verheijen FGA, Van der Velde M, Bastos AC. A quantitative review of the effects of biochar application to soils on crop productivity Rusing meta-analysis. Agric Ecosyst Environ. 2011;144:175-187. DOI: 10.1016/j.agee.2011.08.015.

[44] Vaccari FP, Maienza A, Miglietta F, Baronti S, Di Lonardo S, Giagnoni L, et al. Biochar stimulates plant growth but not fruit yield of processing tomato in a fertile soil. Agric Ecosyst Environ. 2015;207:163-170. DOI: 10.1016/j.agee.2015.04.015.

[45] Gaskin JW, Speir RA, Harris K, Das KC, Lee RD, Morris LA, et al. Effect of peanut hull and pine chip biochar on soil nutrients, corn nutrient status, and yield. Agron J. 2010;102:623-633. DOI: 10.2134/agronj2009.0083.

[46] Faria WM, Figueiredo CC, Coser TR, Vale AT, Schneider BG. Is sewage sludge biochar capable of replacing inorganic fertilizers for corn production? Evidence from a two-year field experiment. Arc Agron Soil Sci. 2017;505-519. DOI: 10.1080/03650340.2017.1360488.

[47] Biederman LA, Harpole SW. Biochar and its effects on plant productivity and nutrient cycling: a meta-analysis. Glob Change Biol Bioener. 2014;5:202-214. DOI: 10.1111/gcbb.12037.

[48] Shen Q, Hedley M, Camos Arbestain M, Kirschbaum MUF. Can biochar increase the bioavailability of phosphorus. J Soil Sci Plant Nutrition. 2016;16(2):268-286. DOI: 10.4067/S0718-95162016005000022. 